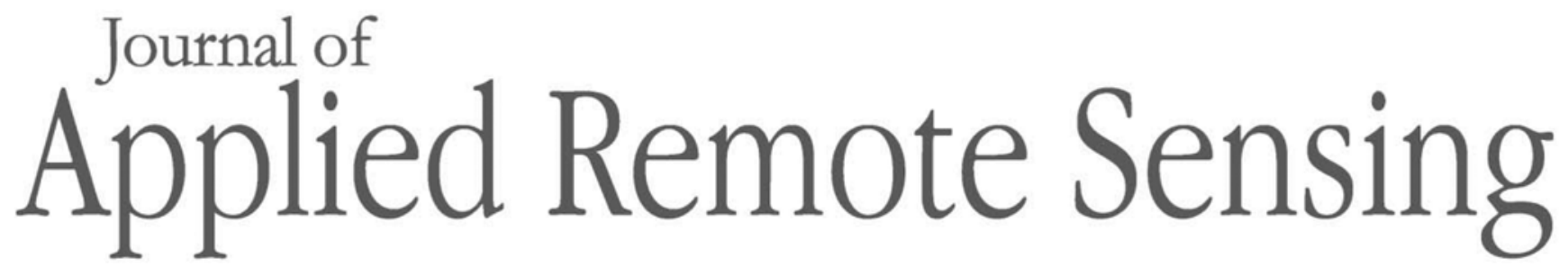

RemoteSensing.SPIEDigitalLibrary.org

\title{
Evaluation of the Tropical Rainfall Measuring Mission 3B43 product over an inland area in Brazil and the effects of satellite boost on rainfall estimates
}

Marcelo Pedroso Curtarelli

Camilo Daleles Rennó

Enner Herênio Alcântara

\section{SPIE.}




\title{
Evaluation of the Tropical Rainfall Measuring Mission $3 B 43$ product over an inland area in Brazil and the effects of satellite boost on rainfall estimates
}

\author{
Marcelo Pedroso Curtarelli, ${ }^{\mathrm{a}, *}$ Camilo Daleles Rennó, ${ }^{\mathrm{b}}$ and \\ Enner Herênio Alcântarac \\ ${ }^{a}$ National Institute for Space Research, Remote Sensing Division, \\ Avenida dos Astronautas, São José dos Campos 12227-010, Brazil \\ ${ }^{b}$ National Institute for Space Research, Image Processing Division, \\ Avenida dos Astronautas, São José dos Campos 12227-010, Brazil \\ ${ }^{\mathrm{c} S a ̃ o}$ Paulo State University, Department of Cartography, \\ Roberto Simonsen Street, Presidente Prudente 19060-900, Brazil
}

\begin{abstract}
The main objective of this study was to evaluate the monthly mean areal rainfall estimated using the Tropical Rainfall Measuring Mission (TRMM) 3B43 version 7 product over an inland area in Central Brazil. Furthermore, we investigated the effect of TRMM orbit boost (in August 2001) over the 3B43 estimates. The TRMM 3B43 estimates were compared to reference rainfall data, collected at 67 rain gauge stations irregularly distributed in the study area. The results showed a good agreement between the TRMM 3B43 areal monthly mean rainfall estimations and reference data $(r>0.97)$. The error analysis showed that the TRMM 3B43 product tends to overestimate the areal monthly mean rainfall at approximately $1.24 \%$. The root-mean-square error (RMSE) for the entire period was $19.66 \mathrm{~mm} \mathrm{month}^{-1}(15.75 \%)$. A Monte Carlo simulation and Wilcoxon statistical test showed that the RMSE increased significantly ( $p$-value $<0.01$ ) after the boost, rising from 15.20 to $23.06 \mathrm{~mm} \mathrm{month}^{-1}$. However, the increase in the RMSE does not preclude the use of the TRMM 3B43 product for estimating the monthly mean areal rainfall over the Upper Paraná watershed. The impacts of boost on TRMM 3B43 estimates were observed only for rainfall rates higher than $250 \mathrm{~mm} \mathrm{month}^{-1}$. (c) 2014 Society of Photo-Optical Instrumentation Engineers (SPIE) [DOI: 10.1117/1.JRS.8.083589]
\end{abstract}

Keywords: Tropical Rainfall Measuring Mission; 3B43 product; precipitation; orbit change; upper Paraná watershed.

Paper 14197 received Apr. 10, 2014; revised manuscript received Jun. 20, 2014; accepted for publication Jun. 23, 2014; published online Jul. 18, 2014.

\section{Introduction}

The hydrological regime of a region is determined by its physical, geological, topographical, and climate characteristics, with rainfall as the main climate factor. ${ }^{1}$ Thus, accurately estimating rainfall in space and time is a fundamental task, for example, to detect drought-prone areas for agricultural purposes, ${ }^{2}$ mapping the wildfire potential, ${ }^{3}$ and for water balance studies. ${ }^{4}$ However, to generate a reliable estimate of rainfall, it is necessary for the study area to have a dense monitoring network, with rain gauges distributed regularly throughout the area and with consistent records made. ${ }^{5}$

With a few exceptions, Brazil has a sparse and irregular rain gauge network, with 8102 rain gauges in total, of which 5376 are under the responsibility of the Brazilian Water Agency (ANA) and 2726 under other Brazilian agencies. ${ }^{6}$ Most of the Brazilian watersheds have a rain gauge station density lower than that recommended by the World Meteorology Organization (WMO), ${ }^{7}$ particularly those in the Central and Northern regions. This low density restricts the accuracy of

*Address all correspondence to: Marcelo Pedroso Curtarelli, E-mail: mpedroso@dsr.inpe.br

0091-3286/2014/\$25.00 (C) 2014 SPIE

Journal of Applied Remote Sensing

083589-1

Vol. 8, 2014 
hydrological studies in some parts of the Brazilian territory, requiring the use of other methods to accurately estimate the rainfall.

The retrieval of rainfall information using remote sensing data is an alternative approach for remote areas with no ground data or a sparse monitoring network, such as parts of the Brazilian territory. Various methods to retrieve rainfall from remotely sensed data have been developed in the past decade, and the rainfall products derived have reached a good level of maturity. ${ }^{8}$

The main advantage of remote sensing techniques is the possibility of obtaining continuous and repeated rainfall data throughout space and time, and occasionally with a higher sampling rate than that obtained with rain gauge stations. ${ }^{9}$ Nevertheless, these estimates are subject to errors and uncertainties and thus require evaluation of using ground station rainfall data before use. ${ }^{10,11}$

One of the remote sensing satellites most widely used to retrieve rainfall is the Tropical Rainfall Measuring Mission (TRMM). The TRMM satellite is the result of a partnership between National Aeronautics and Space Administration and Japan Aerospace Exploration Agency, with the main objective of monitoring and studying the rainfall in tropical and subtropical regions. ${ }^{12}$ The TRMM satellite carries five sensors on its payload, a precipitation radar (PR), the TRMM Microwave Imager (TMI), a visible and infrared (IR) scanner, a cloud and earth radiant energy sensor, and a lightning imaging sensor. Each sensor has distinct purposes and measures energy at different ranges of the electromagnetic spectrum.

The TRMM satellite was launched in November 1997 with an estimated lifetime of 3 years. However, in August 2001, the TRMM satellite was subjected to an increase in the altitude of its orbit (hereafter referred to as a boost) to extend its operating time, resulting in changes in some characteristics of its onboard sensors. ${ }^{13}$ Subsequently to the boost, many algorithms used to retrieve the precipitation from the TRMM data were modified in order to account for as many of the effects as possible. Nevertheless, some studies have showed that, despite these changes in the algorithms, an increase in the errors was noticeable after the boost procedure. ${ }^{14,15}$ However, these studies were conducted over oceanic areas, which are subject to different precipitation patterns and processes compared with inland areas.

The main problems of the boost for estimating rainfall, as reported in the literature, are the mismatch between the transmission and reception angles (the rain intensity tends to be weak in the latter half of the scan), the sensitivity degradation by the satellite's altitude increased (the proportion of weak rain echoes that cannot be detected has increased), and the increase of footprint size (the sampling height of near-surface rain has risen). ${ }^{14-16}$

In the past few years, some studies have been conducted in Brazil to validate and evaluate the TRMM rainfall estimates over different areas. ${ }^{11,17}$ However, none of these studies had investigated the effects of the boost on TRMM rainfall estimates. Thus, the following questions need to be answered: (1) Are the rainfall estimates provided by TRMM 3B43 product over central Brazil reliable? (2) Did the change in orbit affect the monthly TRMM rainfall estimates over this inland area? To attempt to answer these questions, this study has the central objectives of evaluating the monthly mean areal rainfall estimated by the TRMM satellite (3B43 product), and investigating the effects of the TRMM orbital boost on the rainfall estimates over the Itumbiara Reservoir drainage area in Central Brazil.

\section{Materials and Methods}

\subsection{Study Area and Reference Rainfall Data}

The study area consists of the Itumbiara Reservoir drainage area, located at the Upper Paraná Basin, in a region that stretches between the Minas Gerais and the Goiás States, Central Brazil [Fig. 1(a)]. The Itumbiara Reservoir was formed by the damming of the Parnaiba River, which flooded its main tributaries (the Araguari and Corumbá Rivers), creating a lake with a dendritic pattern that covers an area of approximately $814 \mathrm{~km}^{2}$ [Fig. 1(b)]. The drainage area that contributes to the reservoir's inflow is approximately $98,000 \mathrm{~km}^{2}$ and includes parts of the Goiás and Minas Gerais States, in addition to part of Distrito Federal [Fig. 1(c)]. The relief in the Itumbiara Reservoir drainage area undulates, and higher altitude values are observed in the north, near Brasília, and in the south, in a region known as "Triângulo Mineiro." 
(a)
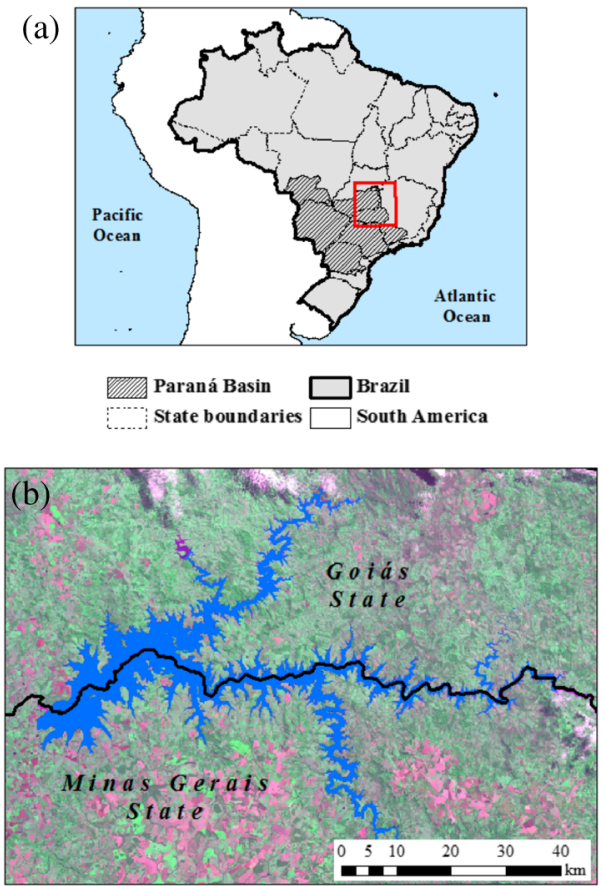

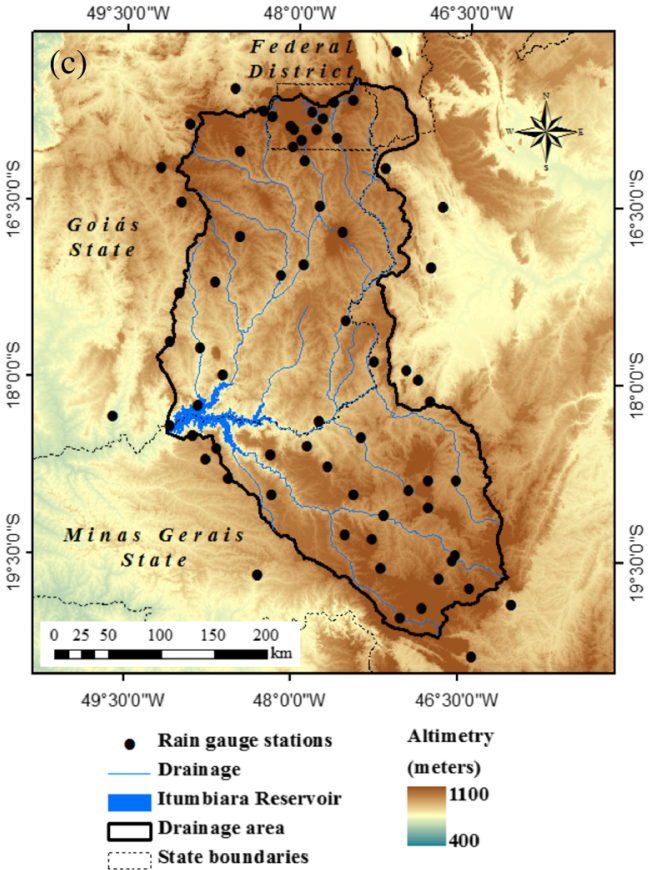

Fig. 1 Study area. (a) Location of the Paraná Basin in Brazil and the Itumbiara Reservoir in the Upper Paraná Basin (red rectangle). (b) Itumbiara Reservoir. (c) Limit, main drainage system, and topography of the Itumbiara Reservoir drainage area. The black points represent the locations of the rain gauge stations used in this study.

The climate in this area is defined as tropical savanna with summer rains, according to the Köppen classification system, ${ }^{18}$ and is characterized by two well-defined seasons: a dry season from April to September and a rainy season from October to March (Fig. 2). The monthly mean rainfall ranges from 130 to $280 \mathrm{~mm} \mathrm{month}^{-1}$ in the rainy season and decreases to less than $10 \mathrm{~mm} \mathrm{month}^{-1}$ during the dry season. The air temperature ranges from $24^{\circ} \mathrm{C}$ to $25^{\circ} \mathrm{C}$ in the rainy season and decreases to $20^{\circ} \mathrm{C}$ in the dry season. The humidity exhibits a behavior similar to the air temperature, but with a small shift of the minimum values for September (47\%), reaching values of approximately $80 \%$ in the rainy season. ${ }^{19}$

The rainfall monitoring network in this part of the Paraná Basin is sparse, with only 67 conventional, irregularly distributed rain gauge stations under the responsibility of ANA [see Fig. 1(c)]. The rain data at each station are measured daily, at 7:00 a.m. (local time), and represent the accumulated rainfall in the last $24 \mathrm{~h}\left(\mathrm{~mm} \mathrm{day}^{-1}\right)$. In this study, we used the rainfall data collected by the 67 gauge stations available inside and near the Itumbiara Reservoir drainage area as reference data [see Fig. 1(c)]. The ANA database provides rainfall data at daily

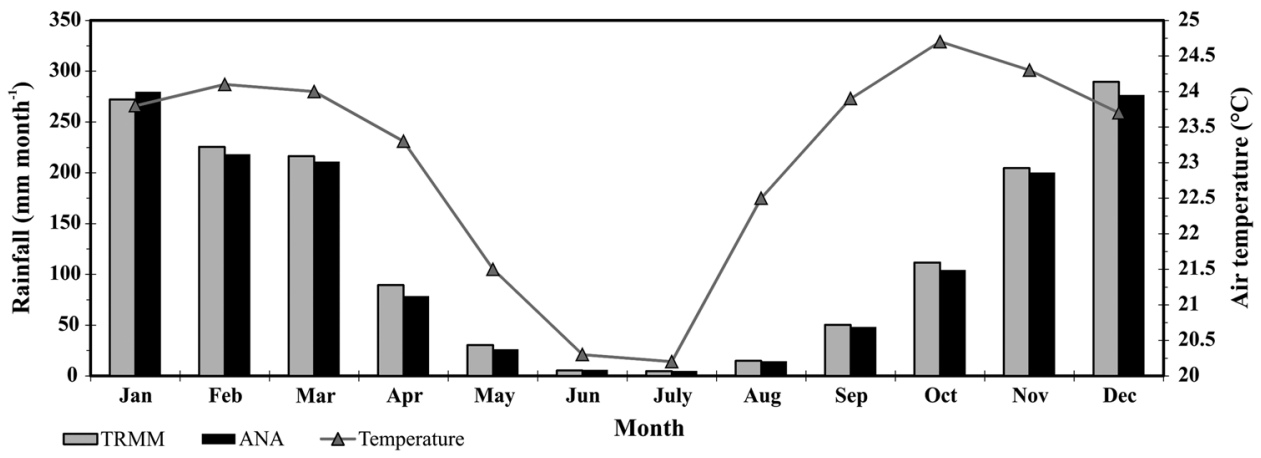

Fig. 2 Interannual variation of rainfall (black and gray bars) and air temperature (gray line) in the Itumbiara Reservoir region. 
$\left(\mathrm{mm} \mathrm{day}^{-1}\right.$ ) and monthly (mm month ${ }^{-1}$ ) time scales and at level 2 consistency (at this level, the data were only organized and the gaps were not filled). The monthly level 2 rainfall data between January 1998 and December 2009 were obtained from the National Information System for Water Resources. ${ }^{20}$

\subsection{Evaluation of Rain Gauge Station Density}

The evaluation of rain gauge station density inside the Itumbiara Reservoir drainage area was performed using kernel estimation $(\mathrm{KE}) .{ }^{21,22} \mathrm{KE}$ is a common analysis tool used to determine the local density of point events and to create a field representation. KE is computed using a Gaussian function, $k$, which considers $n$ events (i.e., rain gauge stations) $\left\{u_{i}, \ldots, u_{n-1}\right\}$ contained in a bandwidth $\tau$ around $u$ and the distance $d$ between the position and the $i$ 'th sampling, through the functions represented by the following equation:

$$
\hat{\lambda}_{\tau}(u)=\frac{1}{\tau^{2}} \sum_{i=1}^{n} k\left[\frac{d\left(u_{i}, u\right)}{\tau}\right], d\left(u_{i}, u\right) \leq \tau
$$

This method was applied to verify whether the monitoring network in the study area is satisfactory, and it identifies areas that are well covered and areas where the rain gauge station coverage is lower than that recommended by the $\mathrm{WMO}^{7}\left(1.74 \times 10^{-4}\right.$ station $\mathrm{km}^{-2}$ for inland plains and undulating terrain).

\subsection{TRMM 3B43 Monthly Rainfall Product}

In this work, we used the TRMM 3B43 product version 7, which has the objective of providing the best estimation of monthly rainfall with as small root-mean-square error (RMSE) as possible using passive microwave (MW) and IR data collected by multiple sensors and global rain gauge product produced by Global Precipitation Climatology Center (GPCC). ${ }^{23}$

The MW dataset used to generate the 3B43 product comprises data collected by different sensors: the TMI on board TRMM, the Special Sensor Microwave Imager (SSM/I) on board Defense Meteorological Satellite Program satellites, the Advanced Microwave Scanning Radiometer-Earth Observing System on board Aqua satellite, and the Advanced Microwave Sounding Unit-B and Microwave Humidity Sounder sensors on board the National Oceanic and Atmospheric Administration satellite series. The MW data have strong physical relationship to the hydrometers that result in surface precipitation, but each individual satellite provides a very sparse sampling of the time-space occurrence of precipitation. Even taken together, there are significant gaps in the current 3-h coverage by the passive MW estimates. The IR $(\sim 10.7 \mu \mathrm{m})$ dataset comprises data collected by the international constellation of Geosynchronous Earth Orbit satellites. In contrast with the MW dataset, the IR dataset provides an excellent temporal $(0.5 \mathrm{~h})$ and spatial $(4 \mathrm{~km})$ coverage. The research version of TRMM 3B43 product also uses three additional datasets: the TRMM Combined Instruments, which combines data from TMI and PR sensors (TRMM product 2B31); the GPCC monthly rainfall analysis; and the Climate Assessment and Monitoring System monthly rain gauge analysis.

The TRMM 3B43 algorithm has four stages: (1) the MW estimates are calibrated and combined; (2) IR estimates are created using the calibrated MW precipitation; (3) the MW and IR estimates are combined; and (4) the rain gauge data are incorporated to refine and rescale the estimates of precipitation to monthly intervals. The TRMM 3B43 product is delivered in a georeferenced grid with $0.25 \times 0.25$ deg spatial resolution, monthly frequency, and millimeter per hour units. ${ }^{24}$ The TRMM 3B43 product covers the area between 50 deg south and 50 deg north in latitude and 180 deg west and 180 deg east in longitude. The TRMM 3B43 product time series is available from January 1998 to the present.

The TRMM 3B43 product time series (January 1998 to December 2009) was obtained from the Goddard Earth Sciences Data and Information Services Center (GESDISC). ${ }^{25,26}$ 


\subsection{Reference Data Preprocessing}

Before proceeding with the evaluation of the TRMM 3B43 product, the reference rainfall data were preprocessed to homogenize (via gap filling) entire time series from January 1998 to December 2009 period and to evaluate its consistency. The gap filling was performed using the regional weighting method, as indicated by United Nations Educational, Scientific, and Cultural Organization (UNESCO): ${ }^{4}$

$$
P_{x}=\frac{1}{n} \sum_{i=1}^{n} \frac{N_{x}}{N_{i}} P_{i},
$$

where $P_{x}$ is the monthly rainfall estimated at the station with the gap $\left(\mathrm{mm} \mathrm{month}{ }^{-1}\right), n$ is the number of stations used to fill the gap, $N_{x}$ is the average monthly rainfall observed at the station with the gap $\left(\mathrm{mm}\right.$ month $\left.^{-1}\right), N_{i}$ is the average monthly rainfall observed at the station $i$ (mm month $\left.{ }^{-1}\right)$, and $P_{i}$ is the monthly rainfall observed at the station $i\left(\mathrm{~mm} \mathrm{month}^{-1}\right)$.

The consistency analysis was performed using the double-mass curve (DMC) technique, as suggested by UNESCO. ${ }^{4}$ This method is indicated for regions with homogeneous rainfall, and consists basically of computing and accumulating the precipitation pattern based on the reference rain gauge stations and afterward comparing it with the accumulated rainfall in each rain gauge station. From the 67 stations shown in Fig. 1, we have used 17 as reference to compute the precipitation pattern (Table 1). These stations were considered as references because they have all data from 12 years of analysis and showed adequate consistency.

\subsection{Monthly Mean Areal Rainfall Estimation Using Reference Data}

The reference monthly mean areal rainfall $\left(P_{\mathrm{ANA}}, \mathrm{mm}\right.$ month $\left.^{-1}\right)$ over the Itumbiara Reservoir drainage area was estimated using the Thiessen polygon method, ${ }^{4}$ which considers the

Table 1 Summary of rain gauge stations used as reference to compute the precipitation pattern.

\begin{tabular}{|c|c|c|c|c|}
\hline Station ID & Station name & Latitude (deg) & Longitude (deg) & Altitude $(\mathrm{m})$ \\
\hline 1847003 & Abadia dos Dourados & -18.492 & -47.431 & 784 \\
\hline 1547014 & Área Alfa & -15.962 & -47.981 & 1216 \\
\hline 1847007 & Cascalho Rico & -18.547 & -47.869 & 719 \\
\hline 1846002 & Charqueada do Patrocínio & -18.920 & -46.963 & 1026 \\
\hline 1748000 & Cristianópolis & -17.199 & -48.734 & 832 \\
\hline 2047037 & Desemboque & -20.004 & -47.006 & 976 \\
\hline 1948006 & Fazenda Letreiro & -18.980 & -48.191 & 811 \\
\hline 1746018 & Fazenda Limoeiro & -17.913 & -47.016 & 594 \\
\hline 1548011 & Fazenda Marajá & -15.541 & -48.576 & 735 \\
\hline 1746017 & Fazenda Poções & -17.035 & -46.827 & 561 \\
\hline 1946007 & Fazenda São Mateus & -19.509 & -46.568 & 877 \\
\hline 1846004 & Guimarania & -19.859 & -46.804 & 952 \\
\hline 1946004 & lbiá & -19.451 & -46.549 & 868 \\
\hline 1947007 & Perdizes & -19.335 & -47.273 & 994 \\
\hline 1947006 & Ponte João Cândido & 19.124 & -47.208 & 837 \\
\hline 1946010 & Pratinha & -19.743 & -46.441 & 1141 \\
\hline 1946005 & Salitre & -19.087 & -46.819 & 919 \\
\hline
\end{tabular}


nonuniformity in the spatial distribution of the rain gauge stations. This method is based on drawn polygons corresponding to the area of influence of each station over the drainage area. The Thiessen polygons were extracted automatically using the Analysis toolbox for ArcGIS 10 through the Create Thiessen polygons command.

\subsection{Monthly Mean Areal Rainfall Estimation Using the TRMM 3B43 Product}

The first step toward estimating the monthly mean areal rainfall over the Itumbiara Reservoir drainage area using the TRMM 3B43 product was to convert the unit of rate $\left(\mathrm{mm} \mathrm{h}^{-1}\right)$ to a monthly cumulative unit $\left(\mathrm{mm} \mathrm{month}^{-1}\right)$ by multiplying each monthly grid of the TRMM 3B43 product by the number of hours of the reference month. The monthly mean areal rainfall obtained with TRMM data $\left(P_{3 B 43}, \mathrm{~mm}\right.$ month $\left.^{-1}\right)$ was estimated by the arithmetic average method.

\subsection{Evaluation of Monthly Mean Areal Rainfall Estimated by TRMM 3B43}

In this work, we evaluated a time series of monthly mean areal rainfall over the Itumbiara Reservoir drainage area obtained using the TRMM 3B43 product between January 1998 and December 2009. The evaluation was performed in three ways: (1) using entire time series (from January 1998 to December 2009); (2) using only the preboost period (from January 1998 to August 2001); and (3) using only the postboost period (from September 2001 to December 2009).

In these three cases, the monthly mean areal rainfall estimated using the TRMM 3B43 product was evaluated through the analysis of the error $\left(P_{3 B 43}-P_{\mathrm{ANA}}\right)$, absolute error $(\mathrm{AE})$, bias, mean absolute error (MAE), RMSE, according to Ref. 27. We also conducted the validation at seasonal scale, comparing the mean seasonal rainfall obtained from TRMM 3B43 product and ANA stations.

\subsection{Evaluation of TRMM Boost on the 3B43 Rainfall Estimates}

To determine whether the RMSE of the monthly mean rainfall estimated with TRMM 3B43 over the Itumbiara Reservoir drainage area increased after the satellite boost, a Monte Carlo Simulation (MCS) ${ }^{28}$ was performed to simulate the RMSE before and after the satellite boost.

The preboost dataset comprises 44 pairs of monthly rainfall values (estimated using reference data and 3B43 product from January 1998 to August 2001), and the postboost dataset comprises 100 pairs of monthly rainfall values (estimated using reference data and 3B43 product from September 2001 to December 2009). At each iteration of MCS, random pairs of monthly rainfall values were drawn in both datasets, and the RMSE values were computed and stored. Respecting the central limit theorem, ${ }^{29}$ we used $50 \%$ of the total data for both sets, that is, 22 and 50 for preboost and postboost, respectively. The MCS was performed for 10,000 iterations.

After the MCS, the Wilcoxon signed rank test was applied to verify whether the difference observed after the satellite boost was statistically significant. ${ }^{30}$ The MCS and Wilcoxon test were performed in the $\mathrm{R}$ environment. ${ }^{31}$

\section{Results}

\subsection{Rain Gauge Density Analysis}

Figure 3(a) shows the density of the rainfall gauge stations inside the study area obtained using the KE, and Fig. 3(b) indicates which areas are below (red) and above (green) the WMO recommendation for the density of rainfall stations $\left(1.74 \times 10^{-4}\right.$ stations $\left.\mathrm{km}^{-2}\right){ }^{7}$ The Itumbiara Reservoir drainage area generally has a good monitoring network, with a mean rain gauge station density of approximately $6.10 \times 10^{-4}$ stations $\mathrm{km}^{-2}$.

However, the rain gauge stations are irregularly distributed throughout the area; therefore, some areas are well monitored, and others are not. This irregularity increases the uncertainties in the estimates made using rain gauge station data in areas with a lower station density. 
(a)

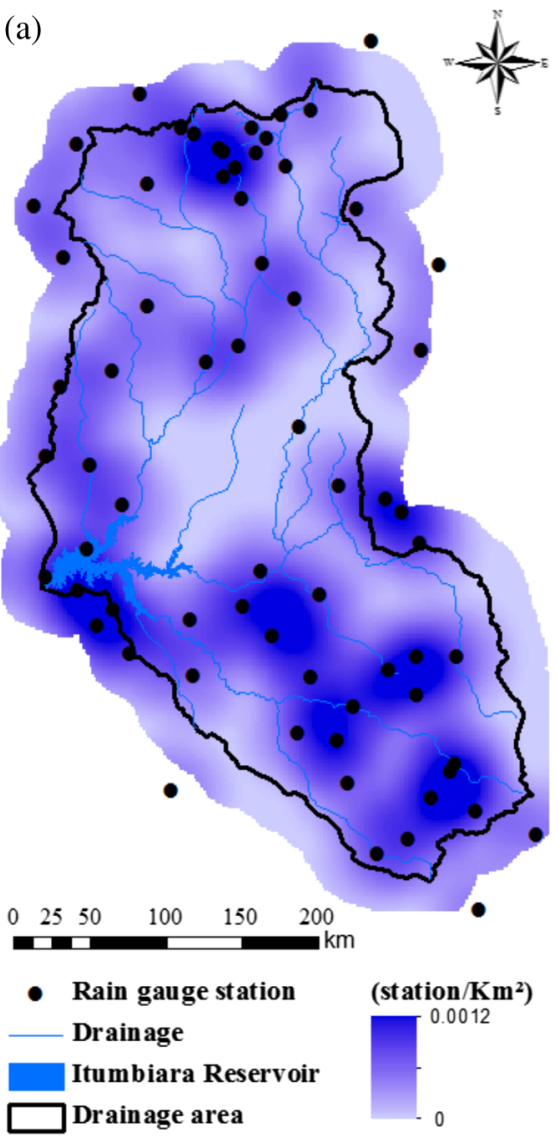

(b)

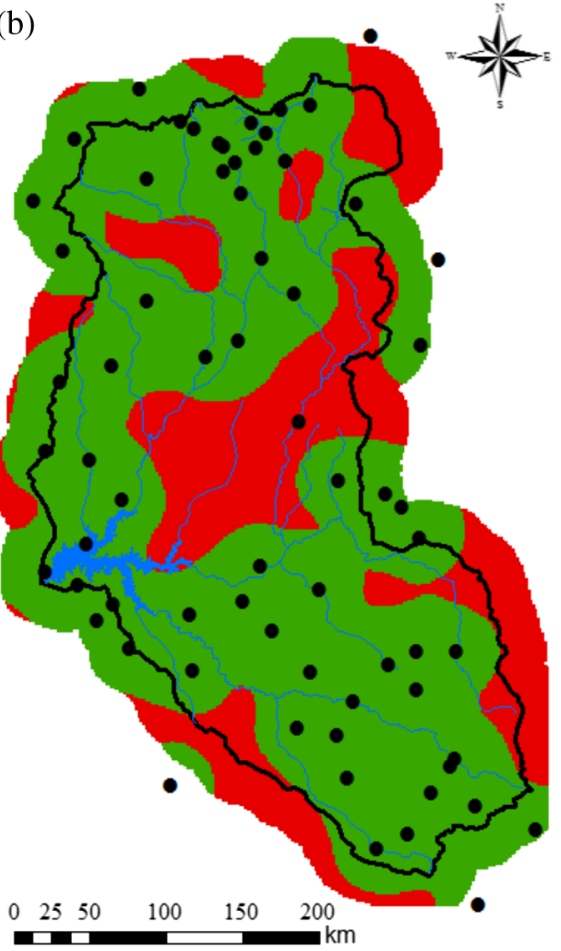

Station density

Lower than recommended by WMO

Greater than recommended by WMO

Fig. 3 Evaluation of rain gauge station density inside the study area: (a) density of rain gauge stations per $\mathrm{km}^{2}$; (b) classification of the densities according to the WMO recommendation. The black points represent the locations of the rain gauge stations.

The higher rain gauge density occurs in the northern region of the study area $\left(2.72 \times 10^{-3}\right.$ stations $\mathrm{km}^{-2}$ ) near Brasília city. Thirteen stations are located here, comprising $19 \%$ of the total rain gauge stations inside the area. Some places near the Itumbiara Reservoir and some parts in the south of the drainage area also have a good rain gauge station density (higher than $1.74 \times 10^{-4}$ station $\mathrm{km}^{-2}$ ). The worst case occurs in the center of the study area, with a rain gauge density near 0 . Approximately $15 \%$ of the Itumbiara Reservoir drainage area has a rain gauge density lower than that recommended by the WMO. ${ }^{7}$

\subsection{Monthly Mean Areal Rainfall Estimated over the Itumbiara Reservoir Drainage Area}

Figure 4 shows the spatial distribution of rain gauge stations, the Thiessen polygons [Fig. 4(a)], and the TRMM grid [Fig. 4(b)] inside the Itumbiara Reservoir drainage area. In this work, we used a total of 67 rain gauge stations and 133 TRMM pixels to estimate the monthly mean rainfall.

The monthly mean areal rainfall estimated using the reference data (black bars) and that estimated with the TRMM 3B43 product (gray bars) for the period from January 1998 to December 2009 are shown in Fig. 5. The monthly mean areal rainfall ranged from 400.76 to approximately $0.52 \mathrm{~mm} \mathrm{month}^{-1}$ along the period. The higher values were observed during December and January (rainy season), when the monthly mean areal rainfall can exceed $280 \mathrm{~mm}$ month $^{-1}$. June and July are the driest months, with monthly mean areal rainfall lower than $10 \mathrm{~mm} \mathrm{month}^{-1}$.

Visually, the two time series have a very similar pattern for the entire period analyzed, and the TRMM 3B43 product was able to correctly estimate the absence of rain during winter, as well as 


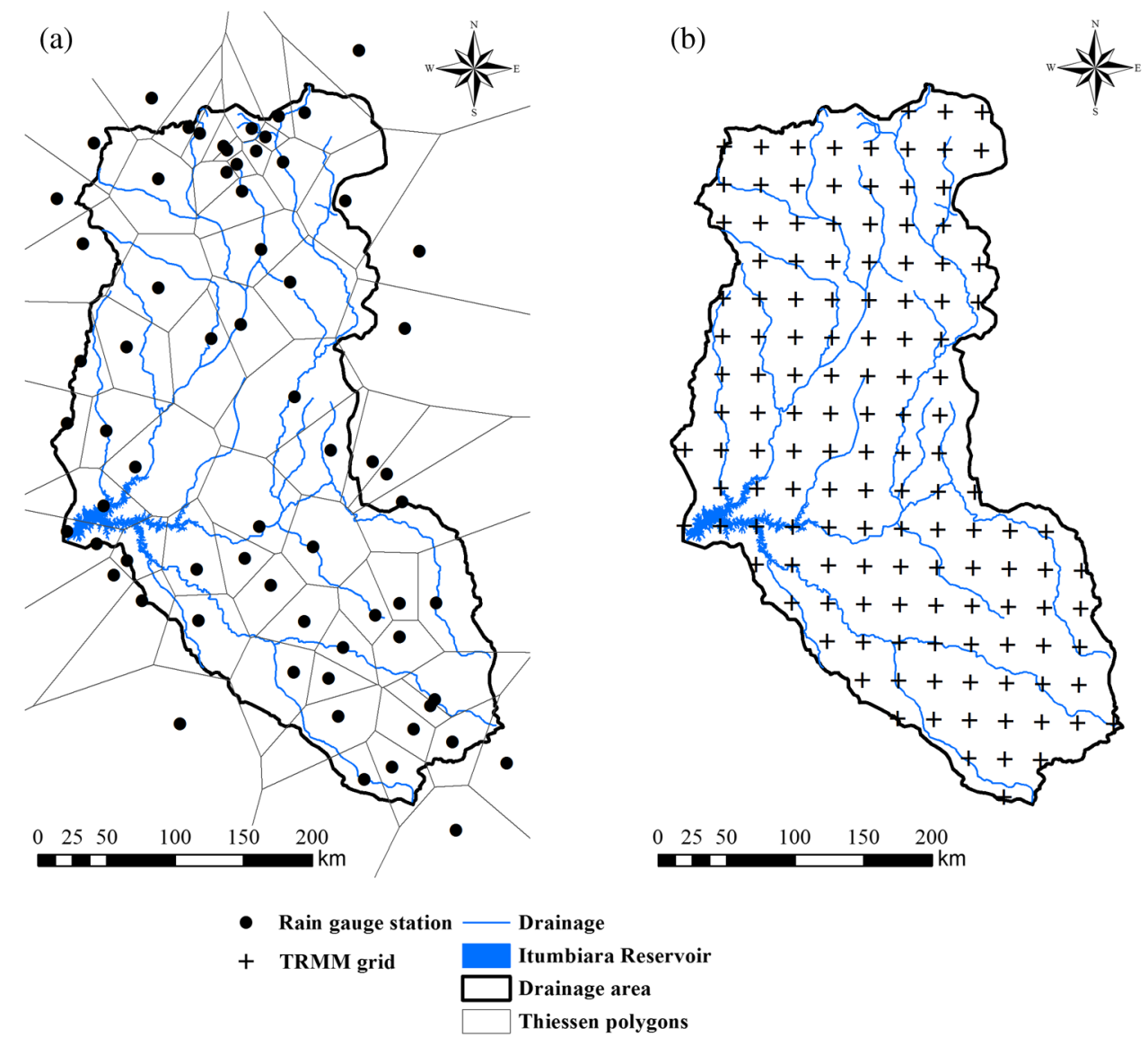

Fig. 4 Estimates of monthly mean areal rainfall: (a) rain gauge stations available and Thiessen polygons; (b) TRMM 3B43 grid inside the study area.

the seasonal changes between the dry and rainy periods. However, the 3B43 product tended to overestimate the precipitation within the study area.

The Pearson correlation analysis (Fig. 6) showed that the monthly mean areal rainfall estimated with the TRMM 3B43 product over the Itumbiara Reservoir drainage area is well correlated with that estimated using the reference data $(r=0.97$, considering the entire periods analyzed). This result is similar to that obtained by Ref. 17, which evaluated the TRMM 3B42 product for the Alto Paraguai basin in Central Brazil, and is higher than that observed by Ref. 11, which evaluated the TRMM 3A25G2 rainfall product over five different areas in Brazil, including Itumbiara region.

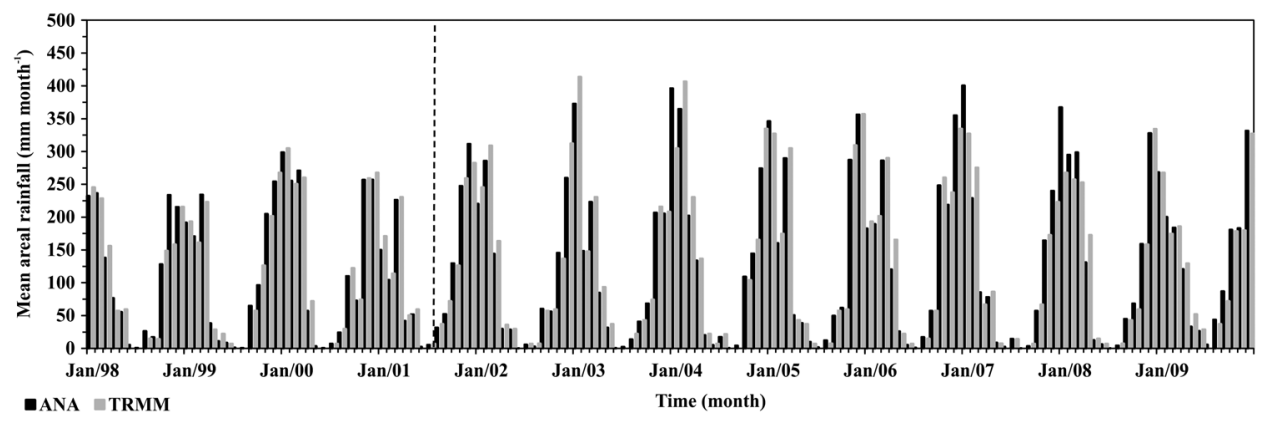

Fig. 5 Time series of the monthly mean areal rainfall over the Itumbiara Reservoir drainage area (from January 1998 to December 2009). Reference rainfall (ANA) is represented by black bars and the TRMM 3B43 estimates by gray bars. The dashed line indicates the time of orbit change (August 2001). 

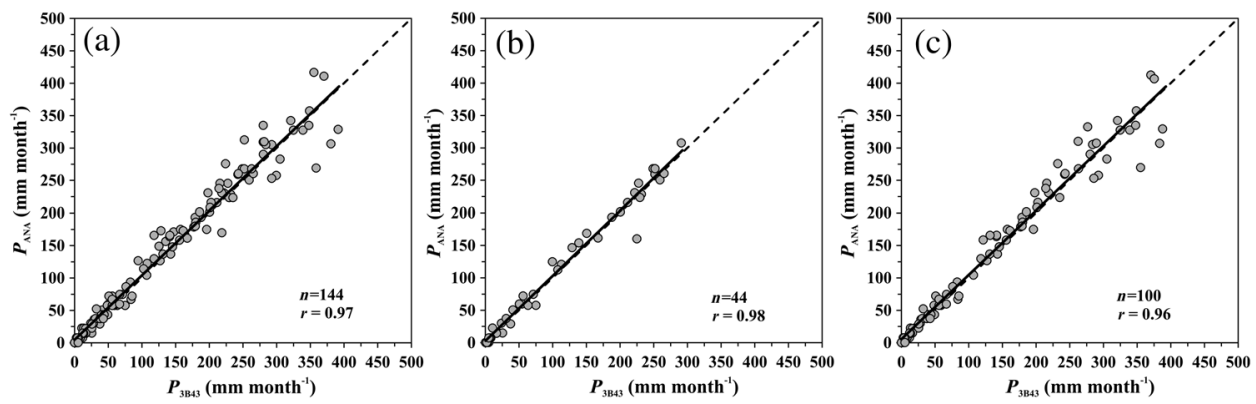

Fig. 6 Scatter-plot between monthly mean areal rainfalls obtained with reference $\left(P_{\mathrm{ANA}}\right)$ and TRMM 3B43 data $\left(P_{3 B 43}\right)$. (a) Entire period (January 1998 to December 2009). (b) Preboost period (January 1998 to August 2001). (c) Postboost period (September 2001 to December 2009).

The correlation between precipitation estimated using rain gauge data and TRMM 3B43 product decreased after the boost [Figs. 6(b) and 6(c)], with $r$ going from 0.98 (before boost) to 0.96 (after boost). It is noteworthy also that after the boost the precipitation rates higher than $250 \mathrm{~mm} \mathrm{month}^{-1}$ showed greater dispersion than those observed for precipitation rates lower than $250 \mathrm{~mm} \mathrm{month}^{-1}$. These results are consistent with those observed by Ref. 14 that investigated the changes in TRMM estimations over the oceans after the boost.

\subsection{TRMM 3B43 Error Analysis}

Figure 7 shows the monthly variability of the error and AE. The error time series [Fig. 7(a)] shows that the estimate based on the TRMM 3B43 data tends to overestimate the monthly mean areal rainfall over Itumbiara most of the time. The error ranged from -97.88 to $57.55 \mathrm{~mm} \mathrm{month}^{-1}$, and there is no clear pattern in the variations observed. The bias calculated for the whole period was approximately $1.24 \mathrm{mmmonth}^{-1}$, which represents approximately $1 \%$.
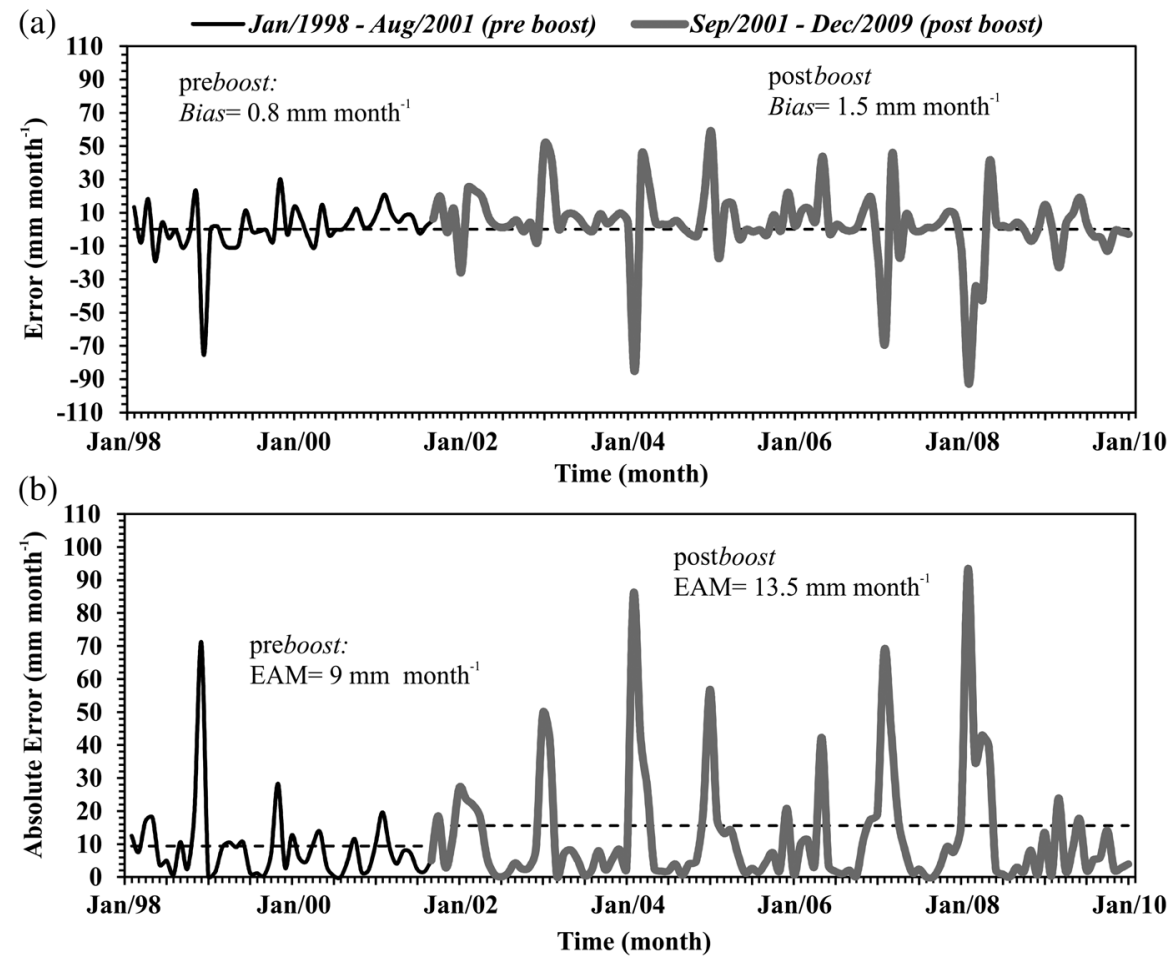

Fig. 7 Error analysis: (a) error time series and (b) absolute error time series. The solid black lines indicate the errors before the boost and the gray solid lines indicate the error after the boost. The dashed lines indicate the bias in (a) and the MAE in (b). 
This same pattern was also observed by other authors in different parts of Brazil, although with higher bias. ${ }^{14,32}$ The separate analysis of bias for the preboost and postboost periods showed an increase of $120 \%$ postboost, rising from $0.82 \mathrm{~mm} \mathrm{month}^{-1}$ (preboost) to $1.50 \mathrm{~mm} \mathrm{month}^{-1}$ (postboost). This result indicates that the orbital boost may have affected the TRMM 3B43 estimates over the Itumbiara Reservoir drainage area.

The AE showed a periodic pattern [Fig. 7(b)], ranging from 0.12 to $97.88 \mathrm{~mm} \mathrm{month}^{-1}$. The highest $\mathrm{AE}$ values were observed during the summertime (December to February), when the precipitation rates exceeded $250 \mathrm{~mm} \mathrm{month}^{-1}$, decreasing toward wintertime (June to August), when the precipitation rates were 10 times lower. This pattern was also observed in Ref. 11 using the TRMM 3A25G2 product in Central Brazil.

The MAE calculated for the entire period analyzed was $11.23 \mathrm{~mm} \mathrm{month}^{-1}(\sim 9 \%)$. Similar to the bias, the MAE increased after the satellite boost, rising from 9.15 to $13.52 \mathrm{~mm} \mathrm{month}^{-1}$, which represents an increase of around $50 \%$.

The RMSE obtained for the entire period was $19.66 \mathrm{~mm} \mathrm{month}^{-1}(15.75 \%)$, rising from $15.59 \mathrm{~mm} \mathrm{month}^{-1}$ (preboost) to $23.09 \mathrm{~mm} \mathrm{month}^{-1}$ (postboost), and is lower than those observed in Ref. 32 for South Brazil. These low values found for the RMSE indicate that the TRMM 3B43 product provides reliable information about the monthly mean areal rainfall over the Itumbiara Reservoir drainage area and can be used instead of conventional rain gauge stations to estimate the rainfall in this area. Table 2 shows a summary of error analysis.

Table 3 shows the summary of the error analysis conducted at seasonal scale [DecemberJanuary-February (DJF), March-April-May (MAM), June-July-August (JJA), and SeptemberOctober-November (SON)]. The bias obtained for each season ranged from -0.12 to $6.71 \mathrm{~mm} \mathrm{month}^{-1}$. The highest value was obtained for MAM period while the lowest value was obtained for JJA period. DJF and SON had a similar bias, with values around $4.4 \mathrm{~mm} \mathrm{month}^{-1}$. The MAE ranged from 2.14 to $15.81 \mathrm{~mm} \mathrm{month}^{-1}$, with the highest value observed during the DJF and the lowest observed during the JJA. As can be noted, the \% MAE for TRMM 3B43 product was lower than $25 \%$ in all seasons. The RMSE ranged from 2.37 to $20.88 \mathrm{~mm} \mathrm{month}^{-1}$. The DJF period showed the highest RMSE and JJA the lowest. The \% RMSE for TRMM 3B43 product was lower than 30\% in all seasons. It is worth noting that although the JJA period showed the lowest values of bias, MAE, and RMSE, the \% errors were the higher during this season. This can be explained due to the low mean areal rainfall

Table 2 Summary of the TRMM 3B43 monthly mean areal rainfall evaluation.

\begin{tabular}{|c|c|c|c|c|c|c|}
\hline & \multicolumn{2}{|c|}{ Bias } & \multicolumn{2}{|c|}{ MAE } & \multicolumn{2}{|c|}{ RMSE } \\
\hline & mm month ${ }^{-1}$ & $\%$ & mm month ${ }^{-1}$ & $\%$ & mm month ${ }^{-1}$ & $\%$ \\
\hline Entire period & 1.24 & 1.03 & 11.23 & 8.82 & 19.66 & 15.75 \\
\hline Preboost period & 0.82 & 0.71 & 9.15 & 8.11 & 15.59 & 14.13 \\
\hline Postboost & 1.50 & 1.25 & 13.52 & 10.33 & 23.09 & 17.58 \\
\hline
\end{tabular}

Table 3 Mean seasonal values for bias, MAE and RMSE.

\begin{tabular}{|c|c|c|c|c|c|c|c|}
\hline \multirow[b]{2}{*}{ Season } & \multirow[b]{2}{*}{$n$} & \multicolumn{2}{|c|}{ Bias } & \multicolumn{2}{|c|}{ MAE } & \multicolumn{2}{|c|}{ RMSE } \\
\hline & & $\mathrm{mm} \mathrm{month}^{-1}$ & $\%$ & $\mathrm{~mm}$ month $^{-1}$ & $\%$ & $\mathrm{~mm} \mathrm{month}^{-1}$ & $\%$ \\
\hline DJF & 12 & 4.43 & 1.59 & 15.81 & 6.20 & 20.88 & 8.22 \\
\hline MAM & 12 & 6.71 & 6.45 & 7.42 & 7.04 & 9.02 & 8.64 \\
\hline JJA & 12 & -0.12 & 1.53 & 2.14 & 24.35 & 2.37 & 28.85 \\
\hline SON & 12 & 4.42 & 3.86 & 8.41 & 7.16 & 9.52 & 8.11 \\
\hline
\end{tabular}


observed during the JJA. The low values observed for the bias, MAE, and RMSE $(<50 \%)$ indicates that the TRMM 3B43 product provides reliable retrievals of rainfall over the study area in all seasons. ${ }^{11}$

In Fig. 8, the mean seasonal rainfall from ANA is plotted against the rainfall estimates from TRMM 3B43 product. For all the seasons, the product TRMM 3B 43 had a good agreement with ground observations, with $r$ ranging from 0.79 to 0.96 . The best agreement was obtained during the autumn (MAM) and the poorest agreement occurred during the summer (DJF). The changes in Pearson coefficient after the boost were not significant. It is worth emphasizing that the errors found in this study cannot be assigned in their entirety to the TRMM estimates, since the methods used to process the reference data also introduced errors in the analyses.

\subsection{Impacts of TRMM Satellite Boost on Rainfall Estimates}

The MCS results are shown in Fig. 9. The values of the RMSE simulated preboost ranged from 14.12 to $17.29 \mathrm{~mm} \mathrm{month}^{-1}$ [Fig. 9(a)], while the RMSE simulated postboost ranged from 14.55 to $26.92 \mathrm{~mm}^{2}$ onth $^{-1}$ [Fig. 9(b)]. The mean value of the RMSE simulated preboost was $15.20 \mathrm{~mm} \mathrm{month}^{-1}$ and postboost was $23.06 \mathrm{~mm} \mathrm{month}^{-1}$, which represents an increase of nearly $8 \mathrm{~mm} \mathrm{month}^{-1}(\sim 51 \%)$ in RMSE. The results of the Wilcoxon signed rank test showed that the null hypothesis was refuted with $5 \%$ significance ( $p$-value $<0.01$; thus, there was a statistically significant increase in the RMSE after the TRMM boost in August 2001.

In order to investigate the impact of boost for distinct rainfall rates, further simulations were conducted for the rainfall rates lower than $250 \mathrm{~mm} \mathrm{month}^{-1}$ [Figs. 9(c) and 9(d)] and higher than $250 \mathrm{~mm} \mathrm{month}^{-1}$ [Figs. 9(e) and 9(f)]. The results showed that for monthly mean areal rainfall lower than $250 \mathrm{~mm} \mathrm{month}^{-1}$ the TRMM orbit boost did not affected the rainfall estimates of 3B43 algorithm. In this case, the RMSE simulated preboost $\left(15.47 \mathrm{~mm} \mathrm{month}^{-1}\right)$ and postboost $\left(15.90 \mathrm{~mm} \mathrm{month}^{-1}\right.$ ) were statistically equal $(p$-value $<0.01)$. On the other hand, for monthly mean areal rainfall rates higher than $250 \mathrm{~mm} \mathrm{month}^{-1}$, the 3B43 estimates were significantly ( $p$-value $<0.01$ ) affected by the TRMM orbit boost. In this case, the RMSE simulated preboost was $19.70 \mathrm{~mm} \mathrm{month}^{-1}$ and postboost was $42.50 \mathrm{~mm} \mathrm{month}{ }^{-1}$, which represents an increase of around $23 \mathrm{~mm} \mathrm{month}^{-1}(122 \%)$.
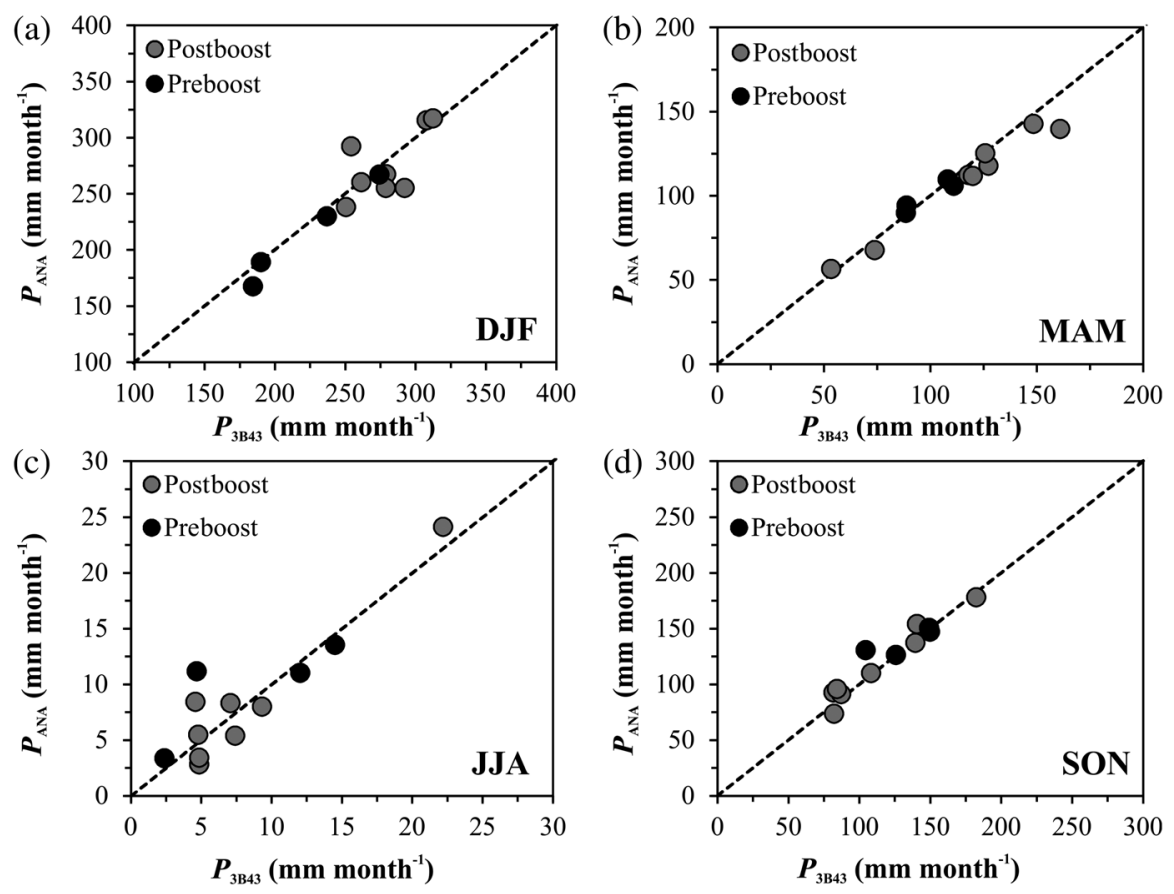

Fig. 8 Mean seasonal rainfall from ANA rain gauge stations versus the rainfall estimates from 3B43 algorithm. (a) Summer (DJF). (b) Autumn (MAM). (c) Winter (JJA). (d) Spring (SON). 

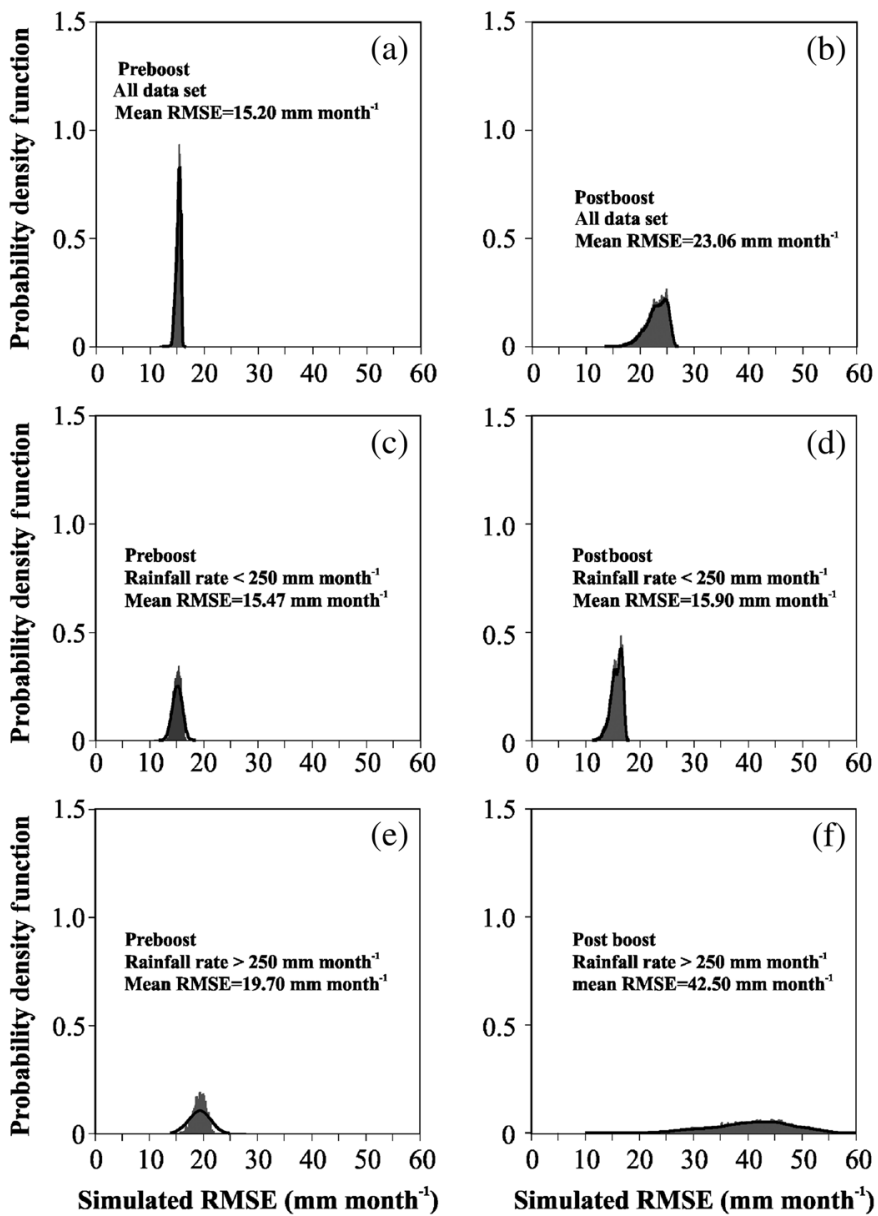

Fig. 9 Histogram of the RMSE simulated using the Monte Carlo Simulation method: All data set (a) preboost period and (b) postboost period; Rainfall rate lower than $250 \mathrm{~mm}$ month-1 data set (c) preboost period and (d) postboost period; Rainfall rate higher than $250 \mathrm{~mm}$ month-1 data set (e) preboost period and (f) postboost period.

\section{Conclusions and Final Considerations}

This work had the objective of evaluating the monthly mean areal rainfall estimated over the Itumbiara Reservoir drainage area using the TRMM 3B43 product, as well as the effects of TRMM orbital change in the rainfall measurements. The main conclusions are as follows:

- There is a good agreement between the monthly mean areal rainfall estimated using the TRMM 3B43 product and in situ data over the Itumbiara Reservoir drainage area $(r>0.97)$. However, the TRMM 3B 43 tends to overestimate the monthly mean areal rainfall by approximately $1.2 \%$.

- The lower values of bias $\left(1.24 \mathrm{~mm}^{-1}\right.$ month $^{-1}$, or $\left.\sim 1 \%\right)$, MAE $\left(11.23 \mathrm{~mm} \mathrm{month}^{-1}\right.$, or $8.82 \%$ ), and RMSE (19.66 mm month ${ }^{-1}$, or 15.75\%) suggest that the TRMM 3B43 product is able to generate reliable estimates of monthly mean areal rainfall over the Itumbiara Reservoir drainage area.

- Although the MAE and RMSE are lower during the wintertime, in absolute values, their relative values are higher $(>20 \%)$. The TRMM 3B43 product showed more reliable estimates during the summer, autumn, and spring period when the MAE and RMSE were lower than $10 \%$.

- After the boost procedure, the RMSE presented a statistically significant ( $p$-value $<0.01$ ) increase of approximately $50 \%$. However, the increase in the RMSE does not preclude the use of the TRMM 3B43 product for estimating the areal rainfall over the Itumbiara Reservoir drainage area. The impacts of boost on TRMM 3B43 estimates 
were observed only for rainfall rates higher than $250 \mathrm{~mm} \mathrm{month}^{-1}$; rainfall rates lower than $250 \mathrm{~mm} \mathrm{month}^{-1}$ did not show significant differences for the periods preboost and postboost.

Further investigations should be conducted to assess the quality of daily and subdaily rainfall estimates provided by TRMM product (3B 42 3-h and daily products) over the study area. Also, the spatial variability of rainfall, provided by $3 \mathrm{~B} 43$ product, needs to be evaluated. Finally, the different datasets used in the TRMM 3B43 algorithm (e.g., PR, TMI, SSM/I data) should be evaluated separately, in order to better evaluate the boost effect on the rainfall estimates.

\section{Acknowledgments}

M.P. Curtarelli is grateful to CAPES for an MSc fellowship during the 2010-2012 period. The authors also thank the São Paulo Research Foundation (FAPESP, under Grant Nos. 2007/081032 and 2010/15075-8), National Institute of Science and Technology for Climate Change (INCT for Climate Change, under Grants CNPq 5737797/2008 and FAPESP 08/57719-9), and ELETROBRÁS-FURNAS.

\section{References}

1. W. Brutsaert, Hydrology: An Introduction, Cambridge University Press, New York (2005).

2. B. R. Paridal et al., "Detecting drought-prone areas of rice agriculture using a MODISderived soil moisture index," GISci. Remote Sens. 45(1), 109-129 (2008).

3. W. H. Cooke et al., "Wildfire potential mapping over the state of Mississippi: a land surface modeling approach," GISci. Remote Sens. 49(4), 492-509 (2012).

4. United Nations Educational, Scientific and Cultural Organization (UNESCO), Methodological Guide for Developing the Water Balance of South America, UNSECO/ ROSTLAC, Montevideo (1982).

5. K.-S. Cheng, Y.-C. Lin, and J.-J. Liou, "Rain-gauge network evaluation and augmentation using geostatistics," Hydrol. Processes 22(14), 2554-2564 (2008).

6. Brazilian Water Agency (ANA), Evolution of the National Hydro-Meteorological Network, ANA, Brasilia (2007).

7. World Meteorological Organization (WMO), Guide to Hydrological Practices: Data Acquisition and Processing, Analysis, Forecasting and Other Applications, WMO, Geneva (1994).

8. C. Kidd and V. Levizzani, "Status of satellite precipitation retrievals," Hydrol. Earth Syst. Sci. 15, 1109-1116 (2010).

9. Y. Hong et al., "Precipitation estimation from remotely sensed imagery using an artificial neural network cloud classification system," J. Appl. Meteorol. 43(12), 1834-1852 (2004).

10. S. E. Nicholson et al., "Validation of TRMM and other rainfall estimates with a high-density gauge dataset for West Africa. Part I: validation of GPCC rainfall product and pre-TRMM satellite and blended products," J. Appl. Meteorol. 42(10), 1337-1354 (2003).

11. S. H. Franchito et al., "Validation of TRMM precipitation radar monthly rainfall estimates over Brazil," J. Geophys. Res. 114(D2), 1-9 (2009).

12. C. Kummerow et al., "The Tropical Rainfall Measuring Mission (TRMM) sensor package," J. Atmos. Oceanic Technol. 15(3), 809-817 (1998).

13. G. J. Huffman and D. T. Bolvin, "TRMM and other data precipitation data set documentation," ftp://precip.gsfc.nasa.gov/pub/trmmdocs/3B42_3B43_doc.pdf (20 October 2012).

14. J. D. DeMoss and K. Bowman, "Changes in TRMM rainfall due to the orbit boost estimated from buoy rain gauge data," J. Atmos. Oceanic Technol. 24(9), 1598-1607 (2007).

15. D.-B. Shin and L. S. Chiu, "Effects of TRMM boost on oceanic rainfall estimates based on microwave emission brightness temperature histograms (METH)," J. Atmos. Oceanic Technol. 25(10), 1888-1893 (2008).

16. D. A. Short and K. Nakamura, "Effect of TRMM orbit boost on radar reflectivity distributions," J. Atmos. Oceanic Technol. 27(7), 1247-1254 (2010). 
17. B. Collischonn et al., "Performance of TRMM satellite precipitation estimates over the Upper Paraguai River Basin,” Braz. J. Cartogr. 59(1), 93-99 (2007).

18. W. L. Donn, Meteorology, Reverté, Barcelona (1978).

19. E. Alcântara et al., "Remote sensing of water surface temperature and heat flux over a tropical hydroelectric reservoir," Remote Sens. Environ. 114(11), 2651-2665 (2010).

20. Brazilian Water Agency, "National Information System for Water Resources," http://www .ana.gov.br/portalsnirh/ (10 September 2013).

21. T. C. Bailey and A. C. Gatrell, Interactive Spatial Data Analysis, Prentice Hall, Upper Saddle River (1995).

22. E. Alcântara et al., "Improving the spectral unmixing algorithm to map water turbidity distributions," Environ. Modell. Software 24(9), 1051-1061 (2009).

23. G. J. Huffman et al., "The TRMM multi-satellite precipitation analysis: quasi-global, multiyear, combined-sensor precipitation estimates at fine scale," J. Hydrometeorol. 8(1), 38-55 (2007).

24. Japan Aerospace Exploration Agency (JAXA), TRMM Data User's Handbook, www.eorc .jaxa.jp/TRMM/document/text/handbook_e.pdf (20 September 2013).

25. Goddard Earth Sciences Data and Information Services Center, "Mirador Data Access," http://mirador.gsfc.nasa.gov/cgi-bin/mirador/ (September 2013).

26. Goddard Space Flight Center, "Tropical Rainfall Measuring Mission,” http://trmm.gsfc.nasa .gov/3b43.html (23 September 2013).

27. Z. Duan and W. G. M. Bastiaanssen, "First results from version 7 TRMM 3B43 precipitation product in combination with a new downscaling-calibration procedure," Remote Sens. Environ. 131, 1-13 (2013).

28. Y. Hong et al., "Uncertainty quantification of satellite precipitation estimation and Monte Carlo assessment of the error propagation into hydrologic response," Water Resour. Res. 42(8), 1-15 (2006).

29. M. Gebremichael et al., "Error uncertainty analysis of GPCP monthly rainfall products: a data-based simulation study," J. Appl. Meteorol. 42(12), 1837-1848 (2003).

30. D. S. Wilks, Statistical Methods in the Atmospheric Sciences, Academic Press, Burlington (2006).

31. R Core Team, R: A Language and Environment for Statistical Computing, http://www .r-project.org/ (18 September 2013).

32. D. R. Viana, N. J. Ferreira, and J. C. Conforte, "Evaluation of precipitation estimates 3B42 and 3B43 TRMM satellite in Southern Brazil," in Proc. of 16th Brazilian Meteorology Symposium, Brazilian Society of Meteorology (SBMET), Pará, Brazil (2010).

Marcelo Pedroso Curtarelli received his BS degree in environmental and sanitary engineering from Federal University of Santa Catarina, Florianópolis, Brazil, in 2010 and an MSc degree in remote sensing from the National Institute for Space Research (INPE), São José dos Campos, Brazil, 2012. Presently, he is a PhD student at INPE. His scientific research focuses on hydrodynamics and carbon cycle modeling in tropical hydroelectric reservoirs located in the Brazilian Amazon.

Camilo Daleles Rennó received his BS degree in agricultural engineering from São Paulo State University "Júlio de Mesquita Filho" in 1992, an MSc degree in remote sensing from National Institute for Space Research (INPE) in 1995, and a PhD degree in remote sensing from INPE in 2003. He is currently a senior technologist level III in the Division of Image Processing at INPE. His main topics of interest include image processing, modeling and hydrological studies of the Amazon.

Enner Herênio Alcântara received his BS degree in aquatic sciences from Federal University of Maranhão in 2005, and MSc and PhD degrees in remote sensing from National Institute for Space Research (INPE) in 2006 and 2010, respectively. He is currently an assistant professor in the Department of Cartography of the São Paulo State University "Júlio de Mesquita Filho," Presidente Prudente Campus. His main areas of focus are remote sensing, GIS, environmental modeling, and water resources. 